August 17, 2011

\title{
Contractor Sales Training: Providing the Skills Necessary to Sell Comprehensive Home Energy Upgrades
}

Many comprehensive home energy efficiency programs rely on contractors as the customer-facing 'front line' to sell energy improvements. Adding sales skills to contractors' existing technical expertise is key to converting more assessments into comprehensive home energy upgrades. Leading programs recognize the need to support contractors with sales and business training to help them succeed and to support the growth of the home performance industry for the long term. A number of contractor sales training efforts are emerging, including some programs that are seeing encouraging early results.

\section{Challenge: Converting Assessments to Comprehensive Energy Upgrades}

While many energy efficiency programs offer free or subsidized home energy assessments (i.e., audits) as a first step toward enticing people to undertake home energy upgrade projects, assessments do not necessarily lead to completed projects. A growing number of program managers and home performance contractors are aware that the key to program success, and the continued success of the home performance industry, is converting assessments into comprehensive home energy upgrades, achieved through homeowner education and skilled salesmanship, in addition to creating a seamless customer experience and other effective program elements.

\section{Workforce Development - Beyond Technical Certification}

Many American Recovery and Reinvestment Act (ARRA) and utility customer-funded residential energy efficiency programs are committed to developing a sustainable workforce of energy efficiency professionals that will serve the market long after ARRA funds are spent. Much of the training has been focused on building science education and technical certification (e.g., BPI, RESNET). However, a number of residential energy efficiency program managers have observed that the increase in contractors with technical training and certification has not necessarily produced the anticipated increase in the number of energy upgrades. Some program administrators, such as Efficiency Maine, realized that one of the 'missing links' in their workforce development efforts was training contractors to sell efficiency. This sales training covers interacting effectively with homeowners and making the pitch in a way that addresses homeowner concerns while also leading to comprehensive energy improvements.

Program administrators, industry associations, and individual contractors are offering a growing number of contractor sales training programs that draw from professional sales training methods, research on targeting and motivating homeowners to make buying decisions and years of professional experience from successful home performance contractors. Efficiency Maine is among the first statewide efficiency program administrators to offer a professional home performance contractor sales training course designed to help contractors bridge the gap between their focus on technical knowledge and addressing homeowner needs and concerns. Efficiency Vermont has recently initiated its own contractor sales training patterned after Maine’s program.

\footnotetext{
This paper is part of the LBNL Clean Energy Program Policy Brief series. These working papers highlight emerging program models, important issues that new programs face, and how these issues are being addressed. To join the email list to receive these policy briefs, please click HERE. The work described in this Policy Brief was funded by the Department of Energy Office of Energy Efficiency and Renewable Energy, Weatherization and Intergovernmental Program under Contract No. DE-AC02-05CH11231. Please direct questions or comments to Megan Billingsley (mabillingsley@lbl.gov).

\section{DISCLAIMER}

This document was prepared as an account of work sponsored by the United States Government. While this document is believed to contain correct information, neither the United States Government nor any agency thereof, nor the Regents of the University of California, nor any of their employees, makes any warranty, express or implied, or assumes any legal responsibility for the accuracy, completeness, or usefulness of any information, apparatus, product, or process disclosed, or represents that its use would not infringe privately owned rights. Reference herein to any specific commercial product, process, or service by its trade name, trademark, manufacturer, or otherwise, does not necessarily constitute or imply its endorsement, recommendation, or favoring by the United States Government or any agency thereof, or the Regents of the University of California. The views and opinions of authors expressed herein do not necessarily state or reflect those of the United States Government or any agency thereof or the Regents of the University of California.
} 


\section{Efficiency Maine - Contractor Sales Training}

Efficiency Maine launched a new whole home performance program in January 2010. Program goals are to complete 4,000 comprehensive energy upgrades within 2 years (900 in the first year), with a target of $20 \%$ energy savings per home. This goal represents a 100-fold increase over energy upgrades completed under the previous Home Performance with Energy Star program. Currently over 100 BPI-certified home performance contractors, have been approved to participate. Efficiency Maine's market-based program does not prescribe pricing for energy improvements, assign leads to contractors or dictate any particular business model; participating contractors can offer services that range from assessments only to complete turnkey home performance services. Program support includes rebates, access to financing, and project quality assurance.

\section{Two different worlds - contractors and homeowners}

The first 6 months after program launch were "painfully slow," according to Andy Meyer, Efficiency Maine's residential programs manager. Though they received 10,000 leads through the call center and website, by the end of June 2010, only 72 upgrades had been completed, far short of a trajectory that would meet their goals. By shadowing the contractors on home visits, program managers gained a critical insight - contractors and homeowners were not connecting; they were operating in two different worlds. The home performance contractors were focused on demonstrating their building science expertise, and they spoke in technical language about the issues they were finding, which often frightened homeowners and derailed the sales process. The staff realized they had done a good job with providing technical training to contractors, but had not trained them on how to communicate effectively with homeowners.

\section{A focus on homeowner needs}

Efficiency Maine undertook a national search for a sales training program and decided to partner with Dale Carnegie, which had a local presence in Maine. Carnegie and Efficiency Maine worked together to fully customize the Carnegie sales model for home performance, blending selling techniques and building science, recognizing that the contractors did not want to think of themselves as salespeople. The sales model is homeowner needs-focused and addresses the various sales stages that the contractors encounter, from prospecting and conducting assessments to selling upgrades, following up and getting referrals. The sales process integrates two key documents, providing consistency throughout the state: 1) the comprehensive assessment (e.g. audit) checklist, which includes customer qualification questions; and 2) the proposal template which starts with a section addressing homeowner needs and interests rather than building science.

\section{Results}

The 2-day sales training program launched in August 2010. Over 30 contractors took the training that fall. An additional 27 contractors took the training in early 2011. During the summer of 2010 , the monthly ratio of assessments to completed projects averaged about 10 percent. Within 2 months after the August and September training, conversion rates increased to a 30 percent per month average. By the end of December 2010 , conversion rates reached 60 percent per month, and Mainers had completed 1,800 home energy upgrades achieving an average energy savings of 29 percent. While there were other contributing initiatives during that time, including rebates that ended December 31, program managers believe that the sales training has been a key success factor. Monthly conversion rates remained strong during April and May 2011, averaging over 50 percent. As a result of the training, contractors reported that they have changed the way they do business. Program managers anecdotally reported that the contractors were speaking differently with homeowners and starting to close more jobs.

\section{Next steps}

Efficiency Maine provides other support, such as co-op marketing (where marketing costs are shared between Efficiency Maine and the contractors) for its energy advisors, and is looking for additional ways to support market transformation. 


\section{Where There's a Will - Contractors Can Find a Way}

In addition to energy efficiency program-initiated sales training courses, contractors themselves have observed that in order to succeed, they need to learn how to motivate the homeowner to go beyond the reactive actions of replacing a broken $\mathrm{A} / \mathrm{C}$ unit or furnace and on to more comprehensive (and costly) upgrades. However, making the case to the homeowner for upgrades that address not only efficiency, but health, safety and comfort, has not come easily to the contractor community. To help address these challenges, industry leaders and trade associations are developing a number of sales training and business development tools and courses.

\section{Practitioners as trainers}

The Affordable Comfort Institute (ACI) hosts national and regional events providing speakers and information about the latest tools, policies, business practices and technical best practices for the home performance and weatherization industry. The 2011 ACI National Home Performance Conference featured a 'short course' on sales and marketing strategies for the home performance contractor taught by Mike Gorman. This course, and others like it, offer contractors valuable tips for running a healthy, profitable business, and often include tools that contractors can immediately put into practice.

\section{Online resources: Learn when you have the time}

In addition to the classroom based courses or seminars, there are a number of online resources that contractors can tap into. Efficiency First, a nonprofit trade association for home performance professionals, provides members with access to webinars on a wide range of topics, from financing to marketing to improving business practices and updating contractors on the latest policy initiatives.

The Electric \& Gas Industries Association (EGIA) provides a number of business support programs ${ }^{1}$ in addition to their Leadership Academy which fosters business development and contractor participation in local utility and government programs through a series of webinars, presentations, and workshops. Courses include Sales 101, Marketing Home Performance, and many others.

\section{Join the (contractor) social network!}

For many contractors, the best guidance and tips for selling home performance may come from their peers. Home Energy Pros, is a global social network and community by and for home energy professionals. The site provides a forum for contractors to share their experiences and includes blogs from industry leaders, a calendar of upcoming industry events, and a library of resources on home energy efficiency. There is a dedicated group dedicated to Marketing Energy Efficiency, which has discussed everything from identifying target markets to sales aids for Energy Star 'Cool Roof’ Radiant Barrier coatings

\footnotetext{
${ }^{1}$ Business support programs include discounted business insurance, employee benefits, customer billing \& collections, payroll processing, website development, and a financing program for contractors \& their customers.
} 


\section{“Salesman” vs. "Decision Engineer” - A Contractor's Advice}

Like many other contractors, Mike Gorman has an aversion to the label "salesman.” Instead, he considers himself a "decision engineer." Gorman notes that for those contractors concerned about mastering sales skills, anyone who has convinced their partner to marry them has already shown that they have the skills, they just need to learn how to apply those skills to home performance.

Gorman's key message is that for most of the work done in a home contractors have a system or process that they follow to ensure that the job is done correctly. Sales and marketing shouldn't be any different. The process starts when a contractor first picks up the phone to talk to a prospective customer. The contractor should use a pre-planned series of questions to help build trust with the homeowner, identify underlying concerns the homeowner has about their home and screen out folks who are looking to gather quotes for the lowest bid. This helps the contractor prioritize the prospects most likely to complete a whole home upgrade.

For the first home visit, Gorman emphasizes a need to find common ground with the homeowner through friendly conversation such as bonding over the unseasonable weather or a mutual hobby. This helps break the ice and establish a rapport. From there, it's largely an education process for both parties. The contractor needs to listen and understand the needs and concerns of the homeowner, and in turn, educates the homeowner about some of the common problems they are looking for and what can be done to resolve the homeowner's concerns. Gorman suggests involving the homeowner in the assessment whenever possible without putting them in a dangerous situation. For example, placing an infrared camera in the hands of the homeowner and explaining exactly what they are looking at can be very powerful.

Gorman recommends sitting the homeowner down at the kitchen table to discuss the results of the assessment. If a contractor can prepare the report and proposal at the time of the assessment, they are in a stronger position to discuss the next steps and identify a path to move forward. If a homeowner isn't willing or able to complete all of the recommended upgrades at once, a contractor can help them think about the proposal as a long term plan, prioritizing the "biggest bang for the buck" measures first and scheduling a yearly check-in with the homeowners to decide on the next upgrade.

\section{Sample Phone Screening Questions:}

Build Trust:

- Who recommended us to you?

- Have you had a chance to visit our website?

- How familiar are you with Home Performance?

Identify Need:

- What are you looking to accomplish?

- When do you want to start the work?

Establish Ability:

- How long have you lived in this house? Are you planning on staying?

- Have you had any remodeling done before?

- Are you planning to pay cash or are you interested in financing? Have you heard about the local program's financing offer? 
Resources for Program Managers - Contractor Sales Training

\begin{tabular}{|c|c|c|}
\hline $\begin{array}{l}\text { Dale Carnegie } \\
\text { Training }\end{array}$ & $\begin{array}{l}\text { Professional sales training program that can be } \\
\text { customized for home performance. Contact Bill } \\
\text { Bertolet, VP of Global Sales, 212-836-0757. }\end{array}$ & Bill.bertolet@dalecarnegie.com \\
\hline Con-Com-T & $\begin{array}{l}\text { Develops professional sales training for the home } \\
\text { performance industry. Contact Jay Gentry, President, } \\
\text { 831-626-1340. Jaycct@gmail.com. }\end{array}$ & http://concomt.com \\
\hline $\begin{array}{l}\text { DOE Solutions } \\
\text { Center }\end{array}$ & $\begin{array}{l}\text { Past webcasts on DOE’s Solutions Center: “Workforce } \\
\text { Development and Sales Training for Energy Efficiency } \\
\text { Contractors,” March 22, 2011; and “Driving Demand: } \\
\text { Working With and Learning from Contractors,” } \\
\text { November 9, } 2010 .\end{array}$ & $\frac{\text { www1.eere.energy.gov/wip/sol }}{\underline{\text { utioncenter/webcasts/ }}}$ \\
\hline LBNL & $\begin{array}{l}\text { "Converting the Assessment into an Upgrade: } \\
\text { Resources for Program Managers \& Contractors” - } \\
\text { available for download on Lawrence Berkeley National } \\
\text { Laboratory’s “Driving Demand” website }\end{array}$ & http://drivingdemand.lbl.gov/ \\
\hline
\end{tabular}

\section{Resources for Contractors - Sales Training and Business Development Support}

\begin{tabular}{|lll|}
\hline $\begin{array}{l}\text { Affordable } \\
\text { Comfort Institute } \\
\text { (ACI) }\end{array}$ & $\begin{array}{l}\text { National and regional events providing speakers and } \\
\text { information about the latest tools, policies, business } \\
\text { practices and technical best practices for the home } \\
\text { performance and weatherization industry }\end{array}$ & www.affordablecomfort.org/ \\
\hline Efficiency First & $\begin{array}{l}\text { A nonprofit trade association for home performance } \\
\text { professionals that gathers information on industry best } \\
\text { practices and champions policy initiatives aimed at } \\
\text { advancing the industry }\end{array}$ & www.efficiencyfirst.org \\
\hline $\begin{array}{l}\text { Electric \& Gas } \\
\text { Industries }\end{array}$ & $\begin{array}{l}\text { A nonprofit organization dedicated to advancing energy } \\
\text { efficiency and renewable energy solutions through a } \\
\text { nationwide network of contractors, distributors, } \\
\text { manufacturers and utility companies }\end{array}$ & www.egia.org \\
\hline Home Energy Pros & $\begin{array}{l}\text { A social network and community for home energy } \\
\text { professionals to exchange ideas, best practices and seek } \\
\text { out advice }\end{array}$ & http://homeenergypros.lbl.gov/ \\
\hline
\end{tabular}

